Ivan Stošić ${ }^{1}$

Jelena Minović ${ }^{2}$
JEL: 047, F02

DOI: 10.5937/industrija42-5276

UDK: $330.341(497-15) ; 005.642 .1$

Original Scientific Paper

\title{
Benchmarking Western Balkan Economies ${ }^{3}$
}

\author{
Article history: \\ Received: 3 December 2013 \\ Sent for revision: 15 December 2013 \\ Received in revised form: 29 January 2014 \\ Accepted: 15 February 2014 \\ Available online: 28 March 2014
}

\begin{abstract}
The aim of this paper is to analyse the relative positions of Western Balkan countries and to determine the differences or similarities in the results based on survey data (of international institutions: EBRD, World Bank, World Economic Forum, Heritage Foundation), and based on selected key statistical indicators. By using the sample of countries in the same region and by applying the method of "multi-country" statistical analysis, it was attempted to establish relation between results obtained in studies of international institutions, and some actually achieved key economic performances by the correlation coefficients (so-called Spearman's and Kendall's). The obtained results differ to a smaller or greater extent according to the experiential test we had used in the case of this region. Therefore, our findings reveal that overall economic position of selected country cannot be perceived only by relying on one methodology or type of data. Consequently, we point out that multi-criteria are a must and each methodology can be useful, because it emphasizes different aspects of the economic performances and country position.
\end{abstract}

Keywords: Benchmarking, the Western Balkans, competitiveness indicators, macroeconomic indicators.

\section{Benčmarkovanje ekonomija zapadnog Balkana}

Apstrakt: Cilj rada je analiza relativne pozicije zemalja zapadnog Balkana $i$ utvrđivanje razlika ili sličnosti u rezultatima koji se temelje na istraživačkim podacima (međunarodnih institucija: EBRD, Svetska banka, Svetski ekonomski forum, Fondacija Heritage) kao i na temelju odabranih ključnih

\footnotetext{
${ }^{1}$ Institute of Economic Sciences, Belgrade, ivan.stosic@ien.bg.ac.rs

2 Institute of Economic Sciences, Belgrade

3 This paper is a part of research projects number 179015 financed by the Ministry of

Education, Science and Technological development of the Republic of Serbia
} 
statističkih pokazatelja. Koristeći uzorak zemalja u istom regionu, a primenom statističke analize za "multi-country" metod, pokušali smo uspostaviti odnos između rezultata dobijenih u studijama međunarodnih institucija i nekih stvarnih postignutih ključnih ekonomskih performansi pomoću koeficijenta korelacije (tzv. Spearmanovog i Kendalovog). Dobijeni rezultati se razlikuju u manjoj ili većoj meri, što je u skladu s iskustvenim testom koji smo koristili u slučaju ovog regiona. Stoga, naši rezultati pokazuju da se ukupni ekonomski položaj odabrane zemlje ne može predvideti oslanjajući se samo na jednu metodologiju ili vrstu podataka. Sledstveno tome možemo istaći da je potrebno imati više kriterijuma, jer svaka metodologija može biti korisna, zato što naglašava različite aspekte ekonomskih performansi i položaj zemlje.

Ključne reči: Benčmarkovanje, Zapadni Balkan, pokazatelji konkurentnosti, makroekonomski pokazatelji.

\section{Introduction}

The main research objective of this paper is to analyse the positions of Western Balkan countries (Albania, Bosnia and Herzegovina, Croatia ${ }^{4}$, FRY Macedonia, Montenegro, and Serbia). Since the positions of certain economies can be measured and ranked in different ways, the additional goal of the paper is to determine the correlation coefficients between the ranks obtained by individual methodologies. Namely, the goal of the study is to determine the first measures of correlation between the scores prepared by international institutions (European Bank for Reconstruction and Development, World Bank, World Economic Forum, and Heritage Foundation), and selected key macroeconomic performances.

But why is the analysis of certain economies position of a region important? The answer to this question lies in the fact, that if the positions of certain economies cannot be measured, they cannot be improved. The identification of the current economic situation in comparison with other competitors and its variation in the period of time are of crucial importance to policy makers, but also to the scientist sectors, for creating, updating, and implementing more efficient economic strategies and policies.

The paper represents one of the rare attempts to identify, especially when considering the Western Balkans region, to which extent the evaluations of eminent international institutions (EBRD, World Bank, World Economic Forum) are in statistically significant correlation with the results of macroeconomic performances of countries in this region. The similar methodology was

\footnotetext{
${ }^{4}$ Croatia became a member state of the EU in July 2013.
} 
implemented in some earlier studies (Lovrinčević, Mikulić \& Rajh, 2008), but with a different research focus and implementation of dissimilar indicators.

Measuring the global economic performances and the analysis of certain countries economic positions is a complicated task. This article presents the problems related to the Western Balkan countries economies positions, and their measurement. Hence, the results of the paper should provide empirically-based and objective evaluation of Western Balkan economies relative positions. The aspiration has been to provide insight and stimulate the discussion among all stakeholders on the best way to benchmark Western Balkan economies. Which one is accurate, which one is inadequate?

Our hypothesis of the research is that objective position of Western Balkan countries and economic progress cannot be perceived only by relying on one methodology or type of data, therefore multi-criteria is a must.

In accordance with the abovementioned, following the introduction, the overview of literature and methodologies used in this paper are presented. The second part of the paper is dedicated to evaluations of results of studies done by international institutions and presentation of statistical data on some key economic indicators of Western Balkan countries. In the third part of the paper, the results of analysis on relation between studies of international institutions and some actually achieved economic performances are presented. Finally, the conclusions of obtained results are made.

\section{Literature review}

The assessment of economic growth, current economic performances and reforms in transition countries, including those from the Western Balkans, were in the focus of numerous studies in the scientific literature.

In the scientific literature in this field, especially in early published papers, it was indicated that the progress in transition basically depends on: start-up position of a country, macroeconomic stability and the level of structural reforms (e.g. De Melo, Denizer, Gelb, \& Tenev, 1997; Fischer, Sahay \& Vegh, 1998; Campos \& Coricelli, 2002). Most papers, e.g. De Melo et al. (1997), find that different starting points are important for economic performance, particularly during the first years of transition. However, the influence of initial conditions declines over time. Berg, Borensztein, Sahay \& Zettelmeyer (1999) showing that the effect diminishes quite rapidly and that country having weak initial conditions is catching up after a delayed recovery.

A number of papers dealing with the phenomenon of countries in transition, as for example Havrylyshyn, Izvorski \& van Rooden (1998), Berg et al. (1999), Barro (2003), Campos \& Coricelli (2002) was based on econometric models 
or specific empirical examinations. Some empirical studies have indicated that significant and positive impact of structural reforms on economic performances cannot be proved at all times. Babetskii \& Campos (2007) analysed 43 econometric studies (with more than 300 different coefficients on the effects of reform on growth), and found out that approximately one third of studies estimated positive and significant influence of reforms on growth, one third negative and significant, and final third insignificant relationship.

Recent scientific literature in this field has been to a great extent focused on significance of accession to EU and transformations that are necessary to be implemented within the accession process (e.g. Bower \& Turrini, 2009; Kose \& Prasad, 2010). Many studies have examined the effects of economic integration on economic growth. The guiding idea of these studies was to determine how big additional economic growth was achieved by accession to EU, and accordingly, certain judgements of "old" and "new" member states of the European Union (Breuss, 2001) or "new" EU member states with countries that have not yet become member states of $\mathrm{EU}$, have been done. There is no uniform conclusion in the scientific literature on significance and direction, or even existence of these effects on economic growth.

The substantial part of scientific literature related to economic growth of transition countries refers to period of so-called "transitional" crisis (mainly in the early nineties of the last century). Nevertheless, the recent period, in which negative impacts of the global economic crisis have manifested, is still not the subject to comprehensive studies. However, some studies, focused on period global crisis, have shown that emerging economies in Europe "suffered" more from consequences of the global crisis and that they are recovering slower compared to developed economies (Becker et al., 2010).

Eftimoski (2006) used human development indicators in order to estimate quality of life in Macedonia. He found that there was no automatic link between the growth of the real income per capita (economic growth) and the growth of the human development index, which mainly resulted from inequal distribution of the benefits among the population (Eftimoski, 2006). Kešeljević (2007) analyzed indexes of economic freedom (Fraser Index, Heritage index, Freedom House Index). He argued that economic freedom was a key link to prosperity and growth. However, this author emphasized that not every type of economic freedom measured in indexes was equally important for economic progress and that the effect of freedom on economic growth largely depends on the direction and magnitude of the change in the economic freedom index over longer period (Kešeljević, 2007). Thus, Kešeljević (2007) pointed out that countries that had more economic freedom also tend to have higher rates of economic growth and were more prosperous.

A part of the research related to issues of transitional changes and economic reforms was dedicated to the Western Balkans. The authors, mostly from this 
region (e.g. Minović, 2011, 2012; Bonetto, Redžepagić \& Tykhonenko, 2009; Ranković, Vasković \& Simović, 2012; Krstić \& Stanišić, 2013) have studied certain economic performances within the region, as well as the challenges in the process of accession to EU. It was pointed out that significant existing progress achieved in the majority of Western Balkan countries still was not satisfactory. In order to fulfil the conditions for progress, to which all countries of the region strive, and also provide the necessary intensive, long-term sustainable economic development and improve the competitiveness of business, it is necessary to implement a number of structural changes in the economic sphere (Stošić \& Erić, 2012).

\section{Method of research}

Measuring the global economic performances and the analysis of certain countries economic positions is a complicated task. Due to complexity of the concepts, various factors, numerous and often very different methodologies can be used, and different indicators can be implemented depending on the research objective.

A lot of different methodologies have been formed and widely applied in the world ${ }^{5}$, but the best known models are the studies of certain international institutions - European Bank for Reconstruction and Development ("Transition Indicators"), World Bank ("Doing business"), World Economic Forum ("Global Competitiveness Index") and Heritage Foundation ("Index of Economic Freedom").

The idea of these studies is to evaluate impartially and on continuous basis, and largely on the basis of strong subjective elements, some key performances of doing business in different countries in the world or some regions. Therefore, an important analytical framework for identifying the relative positions of the economies and monitoring their progress, based on the so-called "soft data" has been created.

In addition to the results of studies of mentioned eminent international institutions, analysis of economic situation and positions of some countries can also be performed based on statistical data on certain macroeconomic performances. Various studies based on these so-called "hard data" are performed

\footnotetext{
${ }^{5}$ IMD world competitiveness yearbook (www. imd.org/ research/ publications/ wcy/index.cfm); Country Risk Reports (www.ihsglobalinsight.com), FDI Confidence Index (www.atkearney.com), Global Production Location Scoreboard (www.global-production.com/ scoreboard), International Country Risk Guide (www.prsgroup.com/ icrg.aspx), World Investment Report (www.unctad.org/wir), Economist Intelligence Unit assessments and other products (www.eiu.com), etc.
} 
all over the world. The results of these studies often differ from the results of abovementioned international institutions.

In the previous period, some econometric examinations were performed (Bienkowski, 2006; Lovrinčević et al., 2008; Tošović Stevanović, 2011), attempting to determine the correlation coefficient between the evaluations presented in the synthetic indicators of World Bank, EBRD, and World Economic Forum with trends of gross domestic product (GDP), export, and foreign investments.

The main objective of this paper, apart from the analysis of economic positions of Western Balkan countries, is to determine the coefficients of correlation between the research results of international institutions (European Bank for Reconstruction and Development, World Bank, World Economic Forum, and Heritage Foundation) and the selected key macroeconomic performances (gross domestic product, export, inflow of foreign direct investments, overall investments, then the level of unemployment, and average monthly gross wages).

The analyses in this paper are based on systemic and logical study of scientific literature as well as "multi-country" comparative empirical examinations of selected external secondary data for Western Balkan region. As a part of the paper, statistical analysis is performed, which has been tested, using Spearman's and Kendall's coefficient of rank correlation, causal relation between study results of international institutions (mainly based on "soft data"), and achieved economic performances ("hard data").

Spearman's (1904) covariance is a nonparametric measure of association that is obtained by computing ordinary covariance on ranked data, where ties are handled using averaging. To compute the Spearman's rank-order covariance and correlation, we simply convert the data to ranks and then compute the centred ordinary counterparts (EViews 7 User's Guide). The simplified expression for the Spearman's rank correlation coefficient is:

$$
\rho=1-\frac{6 \sum_{i}\left(R\left(X_{i}\right)-R\left(Y_{i}\right)\right)^{2}}{N\left(N^{2}-1\right)}=1-\frac{6 \sum_{i} d^{2}}{N\left(N^{2}-1\right)} \text {. }
$$

Where $N$ is the sample size, $R$ is returns the rank of the observation, and $d$ is the difference between the ranks (EViews 7 User's Guide).

Abdi (2007) describes that the Kendall (1955) rank correlation coefficient evaluates the degree of similarity between two sets of ranks given to a same set of objects. The expression for the rank correlation coefficient named as Kendall's tau is: 


$$
\tau=1-\frac{2 \cdot\left[d_{\Delta}\left(\wp_{1}, \wp_{2}\right)\right]}{N(N-1)} .
$$

Where an ordered set on $N$ objects is decomposed into $N(N-1) / 2$ ordered pairs. The symmetric difference distance between two sets of ordered pairs $\wp_{1}$ and $\wp_{2}$ is denoted as $d_{\Delta}\left(\wp_{1}, \wp_{2}\right)$ (Abdi, 2007).

Kendall's tau is a nonparametric statistics that, like Spearman's rank-order statistics, is based on the ranked data. Unlike Spearman's statistics, Kendall's tau uses only the relative orderings of ranks and not the numeric values of the ranks (EViews 7 User's Guide).

We may form a simple measure of the relationship between the variables by considering Kendall's score S, defined as the excess of the concordant pairs C, over the discordant pairs D (EViews 7 User's Guide). Abdi (2007) explained that Kendall's coefficient of correlation was obtained by normalizing the symmetric difference such that it will take values between -1 and +1 . So, $\tau_{a}=+1$ applies if all pairs are concordant, and $\tau_{a}=-1$ applies if all pairs are discordant (EViews 7 User's Guide).

The choice of the Western Balkans - Albania, Bosnia and Herzegovina, Croatia, FRY Macedonia, Montenegro, and Serbia ${ }^{6}$-is based on the fact that these countries are characterized by numerous similarities from the geographic, demographic and from the economic, political, and social aspects, as well their goal to join the EU.

\section{Empirical data and analysis}

\subsection{The evaluation of Western Balkan Countries' position accord- ing to studies of international institutions}

The European Bank for Reconstruction and Development evaluation of position in the transition process - The European Bank for Reconstruction and Development (EBRD) makes the evaluation of the position of certain countries in the transition process. According to the EBRD studies for 2012, average score, grounded on 6 indicators ${ }^{7}$, on the basis of which this institution monitors the progress in transition made by certain countries was 3.36 ("Transition

\footnotetext{
${ }^{6}$ Due to lack of data in studies of European Bank for Reconstruction and Development, World Economic Forum, and Heritage Foundation, Kosovo is not included in this analysis.

${ }^{7}$ Indicators: large scale privatization, small scale privatization, governance and enterprise restructuring, price liberalization, trade and forex system, and competition policy.
} 
report 2012", p. 12). At the same time, average score for Western Balkan countries is somewhat higher, and it is 3.38 .

The evaluation of achieved progress in the process of transition of Western Balkan countries for 2012, according to the results of EBRD studies, is the following:

Table 1. Transitional indicators of Western Balkan countries evaluated by $E B R D$

\begin{tabular}{|l|c|c|}
\hline \multicolumn{1}{|c|}{ Country } & Average score $^{*}$ & Rank in region \\
\hline Albania & 3.50 & 3 \\
\hline Bosnia \&Herzegovina & 3.06 & 6 \\
\hline Croatia & 3.72 & 1 \\
\hline FYR Macedonia & 3.56 & 2 \\
\hline Montenegro & 3.28 & 4 \\
\hline Serbia & 3.17 & 5 \\
\hline
\end{tabular}

Source: Transition report 2012; Notes: * Scale from 1 to 4+.

Most countries in this region had more success in the implementation of the initial stages of reforms, but afterwards the progress was noticeably delayed. Furthermore, the initial enthusiasm and faith that reforms will enable rapid economic progress, was increasingly substituted by slackness in implementing changes, and even disbelief and pessimism regarding soon success of transition (Stošić, Brnjas \& Dedeić, 2010).

Globally, Western Balkan countries accomplished somewhat better results than the rest of the transition countries. According to the EBRD the highest progress was recorded in Croatia and FYR Macedonia, and the lowest in Bosnia \& Herzegovina.

The World Bank evaluation of conditions of "Doing Business" - According to studies of the World Bank, in which conditions of doing business in 185 countries in the world were analysed based on 11 parameters in terms of ease of doing business (starting from the business start-up, providing construction permits, employment, opportunities for crediting business, through the protection of investors, agreements, to the closure of businesses), business environment of Western Balkan countries was ranked in the report "Doing business 2013" in the following way:

Table 2. the evaluation of conditions of Western Balkan countries'operations according to studies of World Bank

\begin{tabular}{|c|c|c|}
\hline Country & Rank in world $^{\star}$ & Rank in region \\
\hline Albania & 85 & 4 \\
\hline
\end{tabular}


Stošić I., Minović J.: Benchmarking Western Balkan Economies

\begin{tabular}{|l|c|c|}
\hline \multicolumn{1}{|c|}{ Country } & Rank in world $^{*}$ & Rank in region $^{*}$ \\
\hline Bosnia \& Herzegovina & 126 & 6 \\
\hline Croatia & 84 & 3 \\
\hline FYR Macedonia & 23 & 1 \\
\hline Montenegro & 51 & 2 \\
\hline Serbia & 86 & 5 \\
\hline
\end{tabular}

Source: Doing business 2013; Notes: "Overall 185 countries ranked.

According to the World Bank's report "Doing Business 2013", FYR Macedonia is the best ranked among the Western Balkan countries regarding conditions of doing business, followed by Montenegro. Other countries in this region hold much worse positions. Therefore, it can be concluded that the current economic and market environment in most countries of the region is not excessively favourable and competitive.

The World Economic Forum evaluation of competitiveness - Since 2005, the World Economic Forum has based its competitiveness analysis on the Global Competitiveness Index ( $\mathrm{GCl}$ ), a comprehensive tool that measures the microeconomic and macroeconomic foundations of national competitiveness with global rankings covering over 100 indicators.

The competitiveness of Western Balkan countries, according to the report of World Economic Forum for period 2012-2013 is the following:

Table 3. The evaluation of Western Balkan countries' competitiveness according to studies of World Economic Forum

\begin{tabular}{|l|c|c|c|}
\hline \multicolumn{1}{|c|}{ Country } & Score & Rank in world & Rank in region \\
\hline Albania & 3.9 & 89 & 5 \\
\hline Bosnia \& Herzegovina & 3.9 & 88 & 4 \\
\hline Croatia & 4.0 & 81 & 3 \\
\hline FYR Macedonia & 4.0 & 80 & 2 \\
\hline Montenegro & 4.1 & 72 & 1 \\
\hline Serbia & 3.9 & 95 & 6 \\
\hline
\end{tabular}

Source: World Economic Forum: The Global Competitiveness Report 2012-2013; Notes: " Overall 144 countries ranked.

According to the report of World Economic Forum for 2012-2013, Montenegro is the best ranked country in Western Balkan region (which is in $72^{\text {nd }}$ place among 144 countries), followed by FYR Macedonia, Croatia, Bosnia \& Herzegovina, and Albania. The worst ranked (to tell the truth with the same score as Bosnia \& Herzegovina and Albania), according to this report, is Serbia (ranked in $95^{\text {th }}$ position). 
Presented indicators of competitiveness do not point out to these countries' economies capabilities for significant improvement of their competitiveness. All countries in this region, according to evaluation of World Economic Forum, are in the so-called Stage 2 - "efficiency driven" economy. The only exemption is Croatia, which evolved into a more advanced development stage towards the so-called "innovation driven" economy.

The Heritage Foundation evaluation of economic freedoms - According to the study of Heritage Foundation ("Index of economic freedom", 2013) which is based on the evaluation of 10 synthetic indicators by which in 177 countries of the world certain aspects of business are monitored. FYR Macedonia is the best ranked country in Western Balkan region (ranked in $43^{\text {rd }}$ position). Albania is ranked in $58^{\text {h }}$ position, followed by Montenegro and Croatia. According to this report, Serbia, and Bosnia \& Herzegovina (ranked in $103^{\text {rd }}$ position) are the worst ranked, with the lowest score.

Table 4. The evaluation of economic freedoms of Western Balkan countries according to studies of Heritage Foundation

\begin{tabular}{|l|c|c|c|}
\hline \multicolumn{1}{|c|}{ Country } & Score $^{*}$ & Rank in world $^{* *}$ & Rank in region $^{*}$ \\
\hline Albania & 65.2 & 58 & 2 \\
\hline Bosnia \&Herzegovina & 57.3 & 103 & 6 \\
\hline Croatia & 61.3 & 78 & 4 \\
\hline FYR Macedonia & 68.2 & 43 & 1 \\
\hline Montenegro & 62.6 & 70 & 3 \\
\hline Serbia & 58.6 & 94 & 5 \\
\hline
\end{tabular}

Source: Index of Economic Freedom 2013; Notes: ${ }^{*}$ The value of index over 80 means freedom, from 70-79.9 means partial freedom, from 60-69.9 moderate freedom, from 50-59.9 mainly nonfreedom, and below 50 suppressed free; "* Overall 177 countries ranked.

Unfortunately, these studies of Heritage Foundation show that the majority of Western Balkan countries (partially with the exception of FYR Macedonia) are ranked fairly poor and fall into the category of the so-called moderately free countries. 


\subsection{Statistical data on some key economic indicators of Western Balkan countries}

In addition to the results of studies of international institutions, analysis of economic progress and positions of some Western Balkan countries can also be performed on the basis of statistical data on some macroeconomic performances, and before all on GDP, as key synthetic indicator of overall achieved results.

In order to ensure their comparability, the indicators from one source were used, i.e. data of the World Bank (mainly for 2011), provided that for some indicators average data were used due to cyclical fluctuations for the period 2009-2011. Data on some key economic indicators of Western Balkan countries, which were used in this analysis, are the following:

Table 5. Data on GDP per capita in US\$, GDP growth, exports, FDI and capital fixed investment as a percentage of GDP, unemployment rate, and average monthly gross wages

\begin{tabular}{|l|c|c|c|c|c|c|c|}
\hline $\begin{array}{l}\text { Economic } \\
\text { indicators }\end{array}$ & Indicator & Albania & $\begin{array}{c}\text { Bosnia \& } \\
\text { Herzegovina }\end{array}$ & Croatia & $\begin{array}{c}\text { FYR Mace- } \\
\text { donia }\end{array}$ & Montenegro & Serbia \\
\hline \multirow{2}{*}{ GDP } & Level & 4,030 & 4,821 & 14,488 & 4,925 & 7,197 & 6,203 \\
\cline { 2 - 8 } & Rank & 6 & 5 & 1 & 4 & 2 & 3 \\
\hline \multirow{3}{*}{ GDP gr. } & Level & 132.8 & 116.5 & 127.5 & 102.2 & 124.2 & 111.7 \\
\cline { 2 - 9 } & Rank & 1 & 4 & 2 & 6 & 3 & 5 \\
\hline \multirow{3}{*}{ UNEM } & Level & 14.3 & 27.6 & 13.5 & 32.0 & 19.7 & 23.0 \\
\cline { 2 - 9 } & Rank & 2 & 5 & 1 & 6 & 3 & 4 \\
\hline \multirow{3}{*}{ WAG } & Level & 292 & 651 & 1,049 & 497 & 722 & 517 \\
\cline { 2 - 9 } & Rank & 6 & 3 & 1 & 4 & 2 & 5 \\
\hline \multirow{3}{*}{ EXP } & Level & 30.0 & 42.3 & 38.3 & 49.4 & 39.1 & 36.7 \\
\cline { 2 - 9 } & Rank & 6 & 3 & 2 & 1 & 4 & 5 \\
\hline \multirow{3}{*}{ FDI } & Level & 10.3 & 1.6 & 6.4 & 3.7 & 19.1 & 4.7 \\
\cline { 2 - 8 } & Rank & 2 & 6 & 5 & 4 & 1 & 3 \\
\hline \multirow{2}{*}{ INV } & Level & 25.8 & 18.9 & 18.4 & 29.2 & 22.0 & 18.4 \\
\cline { 2 - 8 } & Rank & 2 & 4 & 5 & 1 & 3 & 6 \\
\hline
\end{tabular}

Source: World Bank; Notes: GDP = GDP per capita in US\$; GDP gr. = GDP growth 2005-2012; UNEM= Unemployment rate LFS data; $W A G$ = Average monthly gross wages (EUR); EXP=Exports of goods and service as a percentage of GDP (2009-2011); FDI = FDI as a percentage of GDP (2009-2011); INV= Capital fixed investment as a percentage of GDP (2011); Rank = Rank in region . 
According to the GDP per capita Croatia is the best, and Albania is worst ranked country of Western Balkan region. On the basis of GDP growth (in period 2005-2012), the best ranked is Albania, and the worst is FYR Macedonia.

The highest unemployment rate is recorded in FYR Macedonia (worst rank), and the lowest in Croatia (best rank within the region). In line with average monthly gross wages the best ranked is Croatia, and the worst ranked is Albania.

Capital fixed investment as a percentage of GDP points out the level of investments. The highest percentage of capital fixed investment is noted in FYR Macedonia and the lowest in Serbia. The indicator on exports and FDI as a percentage of GDP (in period 2009-2011) indicates export capability and attractiveness of some countries for investment. According to the FDI as an average percentage of GDP the best ranked country of Western Balkan region is Montenegro, followed by Albania, and then Bosnia \& Herzegovina (worst rank).

These data indicate somewhat different picture of achieved results and position of some Western Balkan countries. Therefore, it was interesting to examine whether and to what extent correlation exists between evaluations of international institutions and assessments determined on the basis of statistical data. The next chapter of this paper is dedicated to this question.

\section{Results and discussion}

Positions of some Western Balkan countries, according to their rank in the region, established on the basis of studies of international institutions for 2012, are the following:

Table 6. Rank of Western Balkan countries according to studies of international institutions

\begin{tabular}{|l|c|c|c|c|c|c|}
\hline & EBRD & WB & WEF & HF & Average II & St. Dev. \\
\hline Albania & 3 & 4 & 5 & 2 & 3.5 & 1.3 \\
\hline Bosnia \&Herzegovina & 6 & 6 & 4 & 6 & 5.5 & 1.0 \\
\hline Croatia & 1 & 3 & 3 & 4 & 2.8 & 1.3 \\
\hline FYR Macedonia & 2 & 1 & 2 & 1 & 1.5 & 0.6 \\
\hline Montenegro & 4 & 2 & 1 & 3 & 2.5 & 1.3 \\
\hline Serbia & 5 & 5 & 6 & 5 & 5.3 & 0.5 \\
\hline
\end{tabular}

Source: Authors' calculation; Notes: $E B R D=E B R D ; W B=$ World Bank; WEF $=$ World Economic Forum; $\mathrm{HF}=$ Heritage Foundation; Average $/ I=$ Average rank according to studies of international institutions; St. Dev. = Standard Deviation. 
According to value of average rank, established on the basis of study of relevant international institutions, FYR Macedonia is the best positioned country in the region. Croatia and Montenegro follow, whereas Bosnia \& Herzegovina has the worst average rank in the region.

Positions of some Western Balkan countries vary considerably in different studies of international institutions. This is understandable given that different studies used different methodologies and focused on different performances.

If the results from various studies are compared, it can be concluded that there are the least differences in evaluation of positions of Serbia and FYR Macedonia (relatively small deviation from mean value, the standard deviation is 0.5 , i.e. 0.6). On the other hand, scores for Albania and Croatia vary considerably depending on studies and criteria and therefore significant deviations according to rank (standard deviation higher than 1) were established.

According to rank in the region, established on the basis of statistical data of some macroeconomic indicators, the positions of Western Balkan countries are the following:

Table 7. Rank of Western Balkan countries according to statistical data of some macroeconomic indicators

\begin{tabular}{|l|c|c|c|c|c|c|c|c|c|}
\hline & GDP & GDP gr. & EXP & FDI & INV & UNEM & WAG & $\begin{array}{c}\text { Average } \\
\text { MI }\end{array}$ & $\begin{array}{c}\text { St. } \\
\text { Dev. }\end{array}$ \\
\hline Albania & 6 & 1 & 6 & 2 & 2 & 2 & 6 & 3.6 & 2.3 \\
\hline $\begin{array}{l}\text { Bosnia \& } \\
\text { Herzegovina }\end{array}$ & 5 & 4 & 3 & 6 & 4 & 5 & 3 & 4.3 & 1.1 \\
\hline Croatia & 1 & 2 & 2 & 5 & 5 & 1 & 1 & 2.4 & 1.8 \\
\hline $\begin{array}{l}\text { FYR Macedo- } \\
\text { nia }\end{array}$ & 4 & 6 & 1 & 4 & 1 & 6 & 4 & 3.7 & 2.1 \\
\hline Montenegro & 2 & 3 & 4 & 1 & 3 & 3 & 2 & 2.6 & 1.0 \\
\hline Serbia & 3 & 5 & 5 & 3 & 6 & 4 & 5 & 4.4 & 1.1 \\
\hline
\end{tabular}

Source: Authors' calculation; Notes: GDP = GDP per capita in US\$; GDP gr. = GDP growth 20052012; $E X P=$ Exports of goods and services; $F D I=F D I$ as a percentage of GDP; UNEM =Unemployment rate LFS data; WAG =Average monthly gross wages; Average MI = Average rank according to statistical macroeconomic indicators; St. Dev. =Standard Deviation.

It is interesting to compare the scores - average rank values of studies of international institutions and according to statistical data of some macroeconomic indicators. 
Stošić I., Minović J.: Benchmarking Western Balkan Economies

Table 8. Average rank of Western Balkan countries according to studies of international institutions and according to statistical data of some macroeconomic indicators

\begin{tabular}{|l|c|c|c|}
\hline & $\begin{array}{c}\text { Average rank - inter- } \\
\text { national institutions }\end{array}$ & $\begin{array}{c}\text { Average rank - } \\
\text { statistical data }\end{array}$ & $\begin{array}{c}\text { Average ranks' } \\
\text { difference }\end{array}$ \\
\hline Albania & 3.5 & 3.6 & -0.1 \\
\hline Bosnia \& Herzegovina & 5.5 & 4.3 & 1.2 \\
\hline Croatia & 2.8 & 2.4 & 0.3 \\
\hline FYR Macedonia & 1.5 & 3.7 & -2.2 \\
\hline Montenegro & 2.5 & 2.6 & -0.1 \\
\hline Serbia & 5.3 & 4.4 & 0.8 \\
\hline
\end{tabular}

Source: Authors' calculation

Performed analysis shows that values of average ranks match for Albania and Montenegro, whereas differences are very small in case of Serbia and Croatia. There are larger deviations in ranks for Bosnia \& Herzegovina, and FYR Macedonia.

Eventually, it was attempted to establish relation between scores obtained in studies of international institutions and some actually achieved key economic performances by the first measure of correlation (so-called Spearman's coefficient of correlation, in Table 9).

The results of this analysis show that established ranks for some Western Balkan countries obtained in some studies of the World Bank (WB) have statistically significant correlation coefficient with ranks established in studies of Heritage Foundation (HF), and World Economic Forum (WEF), at the confidence level of $5 \%$, and $10 \%$, respectively. The abovementioned coefficients are positive and considerably high, and they are 0.83 , and 0.77 , respectively. This result slightly differs from the results of Lovrinčević et al. (2008), because first statistically significant measure of correlation among studies of all international institutions, which were the subject of analysis, has been established in that study. First statistically significant measure of correlation was not established in this study between the rank established in studies of EBRD, and in comparative studies of other international institution.

The results of this analysis indicate that first statistically significant measure of correlation could not be established among evaluation ranks of EBRD, World Bank, World Economic Forum, and Heritage Foundation with some key economic performances. 
Stošić I., Minović J.: Benchmarking Western Balkan Economies

Table 9. The Spearman's correlation coefficient for analysed rank variables of Western Balkan countries

\begin{tabular}{|c|c|c|c|c|c|c|c|c|c|c|c|}
\hline $\begin{array}{c}\text { Spear- } \\
\text { man }\end{array}$ & $\begin{array}{c}\text { EBR } \\
\text { D }\end{array}$ & WB & WEF & HF & GDP & $\begin{array}{c}\text { GDP } \\
\text { gr. }\end{array}$ & EXP & FDI & INV & $\begin{array}{l}\text { UN- } \\
\text { EM }\end{array}$ & $\begin{array}{c}\text { WA } \\
\text { G }\end{array}$ \\
\hline EBRD & 1 & & & & & & & & & & \\
\hline WB & $\begin{array}{c}0.714 \\
(2.04 \\
1)\end{array}$ & 1 & & & & & & & & & \\
\hline WEF & $\begin{array}{c}0.371 \\
(0.80 \\
0)\end{array}$ & $\begin{array}{c}0.771 \\
* \\
(2.42 \\
5)\end{array}$ & 1 & & & & & & & & \\
\hline HF & $\begin{array}{c}0.657 \\
(1.74 \\
4)\end{array}$ & $\begin{array}{c}0.829 \\
\star \star \\
(2.96 \\
0)\end{array}$ & $\begin{array}{c}0.429 \\
(0.94 \\
9)\end{array}$ & 1 & & & & & & & \\
\hline GDP & $\begin{array}{c}0.371 \\
(0.80 \\
0)\end{array}$ & $\begin{array}{c}0.371 \\
(0.80 \\
0)\end{array}$ & $\begin{array}{c}0.429 \\
(0.94 \\
9)\end{array}$ & $\begin{array}{c}- \\
0.143 \\
(- \\
0.289 \\
)\end{array}$ & 1 & & & & & & \\
\hline GDP gr. & $\begin{array}{c}0.257 \\
(0.53 \\
2)\end{array}$ & $\begin{array}{c}- \\
0.143 \\
(- \\
0.289 \\
) \\
\end{array}$ & $\begin{array}{c}- \\
0.086 \\
(- \\
0.172 \\
) \\
\end{array}$ & $\begin{array}{c}0.029 \\
(0.05 \\
7)\end{array}$ & $\begin{array}{c}- \\
0.029 \\
(- \\
0.057 \\
\quad \\
\end{array}$ & 1 & & & & & \\
\hline EXP & $\begin{array}{c}0.429 \\
(0.94 \\
9)\end{array}$ & $\begin{array}{c}0.486 \\
(1.11 \\
1)\end{array}$ & $\begin{array}{c}0.600 \\
(1.50 \\
0)\end{array}$ & $\begin{array}{c}0.143 \\
(0.28 \\
9)\end{array}$ & $\begin{array}{c}0.371 \\
(0.80 \\
0)\end{array}$ & $\begin{array}{c}-\bar{c} \\
0.486 \\
(- \\
1.111 \\
\quad \\
\end{array}$ & 1 & & & & \\
\hline FDI & $\begin{array}{c}0.029 \\
(0.05 \\
7)\end{array}$ & $\begin{array}{c}0.371 \\
(0.80 \\
0)\end{array}$ & $\begin{array}{c}0.143 \\
(0.28 \\
9)\end{array}$ & $\begin{array}{c}0.486 \\
(1.11 \\
1)\end{array}$ & $\begin{array}{c}0.029 \\
(0.05 \\
7)\end{array}$ & $\begin{array}{c}0.257 \\
(0.53 \\
2)\end{array}$ & $\begin{array}{c}- \\
0.600 \\
(- \\
1.500 \\
)\end{array}$ & 1 & & & \\
\hline INV & $\begin{array}{c}0.314 \\
(0.66 \\
2)\end{array}$ & $\begin{array}{c}0.600 \\
(1.50 \\
0)\end{array}$ & $\begin{array}{c}0.486 \\
(1.11 \\
1)\end{array}$ & $\begin{array}{c}0.829 \\
\star \star \star \\
(2.96 \\
0)\end{array}$ & $\begin{array}{c}- \\
0.486 \\
(- \\
1.111 \\
) \\
\end{array}$ & $\begin{array}{c}- \\
0.029 \\
(- \\
0.057 \\
\quad \\
\end{array}$ & $\begin{array}{c}0.200 \\
(0.40 \\
8)\end{array}$ & $\begin{array}{c}0.257 \\
(0.53 \\
2)\end{array}$ & 1 & & \\
\hline UNEM & $\begin{array}{c}0.429 \\
(0.94 \\
9)\end{array}$ & $\begin{array}{c}- \\
0.026 \\
(- \\
0.057 \\
)\end{array}$ & $\begin{array}{c}- \\
0.086 \\
(- \\
0.172 \\
)\end{array}$ & $\begin{array}{c}- \\
0.029 \\
(- \\
0.057 \\
\quad)\end{array}$ & $\begin{array}{c}0.371 \\
(0.80 \\
0)\end{array}$ & $\begin{array}{c}0.886 \\
\star \star \\
(3.81 \\
6)\end{array}$ & $\begin{array}{c}- \\
0.371 \\
(0.80 \\
0)\end{array}$ & $\begin{array}{c}0.257 \\
(0.53 \\
2)\end{array}$ & $\begin{array}{c}- \\
0.31 \\
4 \\
(- \\
0.66 \\
2)\end{array}$ & 1 & \\
\hline WAG & $\begin{array}{c}0.257 \\
(0.53 \\
2)\end{array}$ & $\begin{array}{c}0.257 \\
(0.53 \\
2)\end{array}$ & $\begin{array}{c}0.657 \\
(1.74 \\
4)\end{array}$ & $\begin{array}{c}- \\
0.257 \\
(- \\
0.532 \\
\quad)\end{array}$ & $\begin{array}{c}0.771 \\
* \\
(2.42 \\
5)\end{array}$ & $\begin{array}{c}0.086 \\
(0.17 \\
2)\end{array}$ & $\begin{array}{c}0.600 \\
(1.50 \\
0)\end{array}$ & $\begin{array}{c}- \\
0.31 \\
4 \\
(- \\
0.662 \\
)\end{array}$ & $\begin{array}{c}- \\
0.25 \\
7 \\
(- \\
0.53 \\
2)\end{array}$ & $\begin{array}{c}0.257 \\
(0.53 \\
2)\end{array}$ & 1 \\
\hline
\end{tabular}

Source: Authors' calculation; Notes: ${ }^{* *},{ }^{* *}$, and * indicate statistical significance at the 1\%, 5\%, and $10 \%$ levels, respectively; (t-values); EBRD = EBRD; WB = World Bank; WEF = World Economic Forum; HF = Heritage Foundation; GDP = GDP per capita in US\$; GDP gr. = GDP growth 2005-2012; EXP = Exports of goods and service as a percentage of GDP; FDI = FDI as a percentage of GDP; INV = Capital fixed investment as a percentage of GDP; UNEM = Unemployment rate LFS data; WAG = Average monthly gross wages. 
Although it was expected that first statistically significant measure of correlation would be established between evaluations of the World Bank on conditions of doing business, and of EBRD on progress in the transition process, and some of analysed indicators of GDP, such results were not obtained. Tošović Stevanović (2011) also does not find first statistically significant measure of correlation between ranks of WB and GDP, but does find very weak positive correlation coefficient between ranks of EBRD and GDP.

Likewise, first statistically significant measure of correlation between evaluations of World Economic Forum on competitiveness and ranks of some macroeconomic indicators has not been established. Similarly to the results of Lovrinčević et al. (2008), and Tošović Stevanović (2011), it has not been established that there is first statistically significant measure of correlation between inflows of foreign direct investments (FDI), and different indicators of competitiveness, neither between the rank of FDI, and other macroeconomic indicators. Our results indicate that there is no first statistically significant measure of correlation between the rank of Exports of goods and services (EXP), and different indicators of competitiveness, neither between the rank of EXP, and other macroeconomic indicators.

Finally, the results of studies of Heritage Foundation do not have statistically significant correlation coefficient with almost all achieved economic performances of Western Balkan countries. Exceptionally, there is statistically significant correlation coefficient between the rank of Heritage Foundation, and rank of Capital fixed investment (INV), and it is at the confidence level of $5 \%$. The value of coefficient of correlation is positive and it is 0.83 . Therefore we can say that the rank according to Capital fixed investment is significantly correlated only with rank of Heritage Foundation, whereas there is no significant first measure of correlation with all other indices of competitiveness.

However, the Spearman's correlation coefficient (in Table 9) is pairwise correlation. Thus, the Kendall's correlation coefficient is used in order to obtain overall picture about cross-country ranking. Table 10 shows the results of Kendall's tau-a correlation coefficient ${ }^{8}$ for analysed rank variables of Western Balkan countries.

\footnotetext{
${ }^{8}$ Kendall's $\tau_{a}$ is defined as the average of the excess of the concordant over the discordant pairs (EViews 7 User's Guide).
} 
Stošić I., Minović J.: Benchmarking Western Balkan Economies

Table 10. The Kendall's correlation coefficient for analysed rank variables of Western Balkan countries

\begin{tabular}{|c|c|c|c|c|c|c|c|c|c|c|c|}
\hline $\begin{array}{l}\text { Ken- } \\
\text { dall }\end{array}$ & $\begin{array}{c}\text { EBR } \\
\text { D }\end{array}$ & WB & WEF & $\mathrm{HF}$ & GDP & $\begin{array}{c}\text { GDP } \\
\text { gr. }\end{array}$ & EXP & FDI & INV & $\begin{array}{l}\text { UN- } \\
\text { EM }\end{array}$ & $\begin{array}{c}\text { WA } \\
\text { G }\end{array}$ \\
\hline EBRD & $\begin{array}{r}1.000 \\
15 \\
\end{array}$ & & & & & & & & & & \\
\hline WB & $\begin{array}{r}0.600 \\
9 \\
(0.13 \\
3)\end{array}$ & $\begin{array}{r}1.000 \\
15\end{array}$ & & & & & & & & & \\
\hline WEF & $\begin{array}{r}0.200 \\
3 \\
(0.70 \\
7)\end{array}$ & $\begin{array}{r}0.600 \\
9 \\
(0.13 \\
3) \\
\end{array}$ & $\begin{array}{r}1.000 \\
15\end{array}$ & & & & & & & & \\
\hline $\mathrm{HF}$ & $\begin{array}{r}0.600 \\
9 \\
(0.13 \\
3) \\
\end{array}$ & $\begin{array}{c}0.733 \\
11 \\
(0.06 \\
0) \\
\end{array}$ & $\begin{array}{r}0.333 \\
5 \\
(0.45 \\
2) \\
\end{array}$ & $\begin{array}{r}1.000 \\
15\end{array}$ & & & & & & & \\
\hline GDP & $\begin{array}{r}0.333 \\
5 \\
(0.45 \\
2)\end{array}$ & $\begin{array}{r}0.200 \\
3 \\
(0.70 \\
7)\end{array}$ & $\begin{array}{r}0.333 \\
5 \\
(0.45 \\
2)\end{array}$ & $\begin{array}{c}- \\
0.067 \\
-1 \\
(1.00 \\
0)\end{array}$ & $\begin{array}{r}1.000 \\
15\end{array}$ & & & & & & \\
\hline $\begin{array}{l}\text { GDP } \\
\text { gr. }\end{array}$ & $\begin{array}{r}0.200 \\
3 \\
(0.70 \\
7)\end{array}$ & $\begin{array}{c}- \\
0.200 \\
-3 \\
(0.70 \\
7) \\
\end{array}$ & $\begin{array}{c}- \\
0.067 \\
-1 \\
(1.00 \\
0)\end{array}$ & $\begin{array}{r}0.067 \\
1 \\
(1.00 \\
0)\end{array}$ & $\begin{array}{r}0.067 \\
1 \\
(1.00 \\
0)\end{array}$ & $\begin{array}{r}1.000 \\
15\end{array}$ & & & & & \\
\hline EXP & $\begin{array}{r}0.200 \\
3 \\
(0.70 \\
7)\end{array}$ & $\begin{array}{r}0.333 \\
5 \\
(0.45 \\
2)\end{array}$ & $\begin{array}{r}0.467 \\
7 \\
(0.26 \\
0)\end{array}$ & $\begin{array}{r}0.067 \\
1 \\
(1.00 \\
0)\end{array}$ & $\begin{array}{r}0.333 \\
5 \\
(0.45 \\
2)\end{array}$ & $\begin{array}{c}- \\
0.333 \\
-5 \\
(0.45 \\
2)\end{array}$ & $\begin{array}{r}1.000 \\
15\end{array}$ & & & & \\
\hline FDI & $\begin{array}{c}- \\
0.067 \\
-1 \\
(1.00 \\
0)\end{array}$ & $\begin{array}{r}0.333 \\
5 \\
(0.45 \\
2)\end{array}$ & $\begin{array}{r}0.200 \\
3 \\
(0.70 \\
7)\end{array}$ & $\begin{array}{r}0.333 \\
5 \\
(0.45 \\
2)\end{array}$ & $\begin{array}{r}0.067 \\
1 \\
(1.00 \\
0)\end{array}$ & $\begin{array}{r}0.200 \\
3 \\
(0.70 \\
7)\end{array}$ & $\begin{array}{c}- \\
0.333 \\
-5 \\
(0.45 \\
2) \\
\end{array}$ & $\begin{array}{r}1.000 \\
15\end{array}$ & & & \\
\hline INV & $\begin{array}{r}0.333 \\
5 \\
(0.45 \\
2)\end{array}$ & $\begin{array}{r}0.467 \\
7 \\
(0.26 \\
0)\end{array}$ & $\begin{array}{r}0.333 \\
5 \\
(0.45 \\
2)\end{array}$ & $\begin{array}{c}0.733 \\
11 \\
(0.06 \\
0)\end{array}$ & $\begin{array}{c}- \\
0.333 \\
-5 \\
(0.45 \\
2)\end{array}$ & $\begin{array}{r}0.067 \\
1 \\
(1.00 \\
0)\end{array}$ & $\begin{array}{r}0.067 \\
1 \\
(1.00 \\
0)\end{array}$ & $\begin{array}{r}0.067 \\
1 \\
(1.00 \\
0)\end{array}$ & $\begin{array}{r}1.000 \\
15\end{array}$ & & \\
\hline $\begin{array}{l}\text { UN- } \\
\text { EM }\end{array}$ & $\begin{array}{r}0.467 \\
7 \\
(0.26 \\
0)\end{array}$ & $\begin{array}{r}0.067 \\
1 \\
(1.00 \\
0)\end{array}$ & $\begin{array}{c}- \\
0.067 \\
-1 \\
(1.00 \\
0)\end{array}$ & $\begin{array}{r}0.067 \\
1 \\
(1.00 \\
0)\end{array}$ & $\begin{array}{r}0.333 \\
5 \\
(0.45 \\
2)\end{array}$ & $\begin{array}{c}0.733 \\
11 \\
(0.06 \\
0)\end{array}$ & $\begin{array}{c}- \\
0.333 \\
-5 \\
(0.45 \\
2) \\
\end{array}$ & $\begin{array}{r}0.200 \\
3 \\
(0.70 \\
7)\end{array}$ & $\begin{array}{c}- \\
0.200 \\
-3 \\
(0.70 \\
7) \\
\end{array}$ & $\begin{array}{r}1.000 \\
15\end{array}$ & \\
\hline WAG & $\begin{array}{r}0.200 \\
3 \\
(0.70 \\
7)\end{array}$ & $\begin{array}{r}0.067 \\
1 \\
(1.00 \\
0)\end{array}$ & $\begin{array}{r}0.467 \\
7 \\
(0.26 \\
0)\end{array}$ & $\begin{array}{c}- \\
0.200 \\
-3 \\
(0.70 \\
7)\end{array}$ & $\begin{array}{r}0.600 \\
9 \\
(0.13 \\
3)\end{array}$ & $\begin{array}{r}0.200 \\
3 \\
(0.70 \\
7)\end{array}$ & $\begin{array}{r}0.467 \\
7 \\
(0.26 \\
0)\end{array}$ & $\begin{array}{c}- \\
0.333 \\
-5 \\
(0.45 \\
2)\end{array}$ & $\begin{array}{c}- \\
0.200 \\
-3 \\
(0.70 \\
7)\end{array}$ & $\begin{array}{r}0.200 \\
3 \\
(0.70 \\
7)\end{array}$ & $\begin{array}{c}1.00 \\
0 \\
15\end{array}$ \\
\hline
\end{tabular}

Source: Authors' calculation; Notes: Kendall's tau-a, Kendall's Score (S), and (p-values of the score); Included observation is 6. EBRD = EBRD; WB = World Bank; WEF = World Economic Forum; HF = Heritage Foundation; GDP = GDP per capita in US\$; GDP gr. = GDP growth 2005-2012; EXP = Exports of goods and service as a percentage of GDP; FDI = FDI as a percentage of GDP; INV = Capital fixed investment as a percentage of GDP; UNEM = Unemployment rate LFS data; WAG = Average monthly gross wages. 
According to the values of Kendall's rank correlation coefficient (in Table 10), we can see that the smallest distance within Western Balkan region is between the following ranks: World Bank (WB) and Heritage Foundation (HF); HF and Capital fixed investment (INV); and GDP growth and Unemployment rate (UNEM), with Kendall's tau-a of 0.733, and Kendall's score of 11 with $p$ value of 0.06 . This means that we have a large part of the pairs which are concordant. On the other hand, the largest distance with Kendall's tau-a of 0.333 is between following ranks: GDP per capita in US\$ and Capital fixed investment; GDP growth and Exports of goods and service as a percentage of GDP (EXP); EXP and FDI as a percentage of GDP (FDI); EXP and Unemployment rate; FDI and Average monthly gross wages (WAG). In this case we have that 10 pairs are discordant, and just 5 pairs are concordant, because Kendall's score is -5 with p-value of 0.452 .

Further, Kendall's tau-a of 0.600 is between the following ranks: EBRD and World Bank (WB); EBRD and Heritage Foundation; World Bank and World Economic Forum (WEF); and GDP per capita in US\$ (GDP) and Average monthly gross wages (WAG). The Kendall's score of 9 with p-value of 0.133 implies that a large part of the pairs are concordant within Western Balkan region. Finally, Kendall's tau-a of -0.067 is between the following ranks: EBRD and FDI; World Economic Forum and GDP growth; World Economic Forum and Unemployment rate; and Heritage Foundation and GDP per capita in US\$. In this case, Kendall's score is -1 with $p$-value of 1 , which means that 8 pairs are discordant, and 7 pairs are concordant.

\section{Conclusion}

The aim of this paper is to analyse the relative positions of Western Balkan countries and to determine the differences or similarities in the results based on survey data (of international institutions: EBRD, World Bank, World Economic, Forum Heritage Foundation), and based on selected key statistical indicators. Our hypothesis of the research is that objective position of Western Balkan countries and economic progress cannot be perceived only by relying on one methodology or type of data, therefore multi-criteria is a must. According to the outcomes of research the relative positions of certain Western Balkan countries vary to a smaller or greater extent depending on the implemented methodology and indicators. As in a significant number of other studies (for more details see: Babetskii \& Campos, 2007), the implemented statistical analysis failed to establish a firm causal relation between evaluations of studies of international institutions (based to a significant extent on subjective perceptions), and statistical data on macroeconomic performances. Particularly, in the case of FYR Macedonia the significant difference has been observed. That indicates the conclusion that objective position of selected West- 
ern Balkan countries and achieved economic progress cannot be perceived only by relying on one methodology or type of data. There is no strict correlation and convergence in evaluations of certain countries economic progress created on so called "soft" data (survey methodologies of certain international institutions), and actual economic tendencies determined on statistical ("hard") data. Therefore, our hypothesis cannot be rejected.

In the authors' opinion, each method has its advantages and disadvantages. Each of methodologies can be useful, because they emphasize different aspects of the economic performances and country position. Therefore multicriteria is a must on authors' opinion. As countries of certain region compete most directly among each other for the foreign direct and portfolio investments, the results of these researches are very relevant for the business and policy makers, especially in the period of recovering from the outcomes of global economic crisis. The contribution of our research is an empirical finding that the relative position of certain country in a region (in this case the Western Balkans) cannot be determined only by some single methodology and approach. It is of great importance because in some cases we witness easily made estimations on measured relative position and economic progress of a county based only on judgments of an international institution.

Our results suggest that the smallest distance within Western Balkan region, according to Kendall's correlation coefficient, is between the following ranks: World Bank (WB) and Heritage Foundation (HF); HF and Capital fixed investment (INV); and GDP growth and Unemployment rate (UNEM). In this case we have a large part of the pairs which are concordant. On the contrary, the largest distance within Western Balkan region, according to Kendall's correlation coefficient, is between following ranks: GDP per capita in US\$ and Capital fixed investment; GDP growth and Exports of goods and service as a percentage of GDP (EXP); EXP and FDI as a percentage of GDP (FDI); EXP and Unemployment rate; FDI and Average monthly gross wages (WAG). In this case we have 10 discordant pairs, and only 5 concordant pairs.

Unfortunately, a"multi-country" statistical analysis is burdened with numerous problems. There were several limitations to this research which might serve as indications for future research. Our research was restricted by limited data base e.g. data on GDP of some countries significantly vary depending on the source of information. Additionally, some indicators (e.g. report of FDI) vary considerably from year to year. Finally, it is often impossible to obtain updated, internationally comparable data. So, due to lack of data in studies of European Bank for Reconstruction and Development, World Economic Forum, and Heritage Foundation, Kosovo is not included in this analysis.

The authors of the article doubt that scientific discussions about the correlation between study results of international institutions (mainly based on "soft 
data"), and achieved economic performances ("hard data") will end. The results of this paper indicate that future research may be necessary to incorporate econometric analysis, which would include performing correlation analysis of ranks of all indicators for each Western Balkan country separately, thus enabling more precise data. Also, future research may be focused on the comparisons of South East Europe or some other region in Europe or the world.

\section{References}

Abdi, H. (2007). The Kendall Rank Correlation Coefficient. Retrieved from https://www.utdallas.edu/ herve/Abdi-KendallCorrelation2007-pretty.pdf

Babetskii, I., \& Campos, N. (2007). Does Reform Work? An Econometric Examination of the Reform-Growth Puzzle. William Davidson Institute Working Paper Number 870. Retrieved from http://ftp.iza.org/dp2638.pdf

Barro, J. R. (2003). Determinants of Economic Growth in a Panel of Countries. Annals of Economics and Finance, 4, 231-274.

Becker, T., Daianu, D., Darvas, Z., Gligorov, V., Landesmann, M., Petrovic, P., PisaniFerry, J., Rosati, D., Sapir A., \& Weder Di Mauro, B. (2010). Whither Growth in Central and Eastern Europe? Policy lessons for an integrated Europe'. Bruegel, 11. Retrieved from http://aei.pitt.edu/15184/1/101124 bp zd whither growth.pdf

Berg, A., Borensztein E., Sahay R., \& Zettelmeyer J. (1999). The Evolution of Output in Transition Economies: Explaining the Differences. IMF Working Paper, 73, 181. Retrieved from http://www.imf.org/external/pubs/ft/wp/1999/wp9973.pdf

Bienkowski, W. (2006). How much are studies of competitiveness worth? Some critical theoretical reflections on the issue. The Second Economic Forum on "New Europe" II 28-29 April, Lancut.

Bonetto, F., Redžepagić, S., \& Tykhonenko, A. (2009). Balkan Countries: Catching up and their integration in the European financial system. Paneconomicus, 4, 475489.

Bower, U., \& Turrini, A. (2009). EU Accession: A road to fast-track convergence? Economic and Financial Affairs Economic Paper 393. Retrieved from http://ec.europa.eu/economy finance/publications/publication16470 en.pdf

Breuss, F. (2001). Macroeconomic Effects of EU Enlargement for Old and New Members. WIFO Working Papers 143. Retrieved from http://www.wifo.ac.at/jart/pri3/wifo/resources/person dokument/person dokume nt.jart?publikationsid=19815\&mime type=application/pdf

Campos, N. F., \& Coricelli, F. (2002). Growth in Transition: What we know, what we do not know and what we should. Journal of Economic Literature, 40(3), 793-836.

De Melo, M., Denizer, C., Gelb A., \& Tenev, S. (1997). Circumstance and Choice: The Role of Initial Conditions and Polices in Transition Economies. Policy Research Working Paper 1866. The World Bank, Policy Research Department. Retrieved from http://siteresources.worldbank.org/INTDECINEQ/Resources/demelo.pdf 
European Bank for Reconstruction and Development (EBRD). (2012). Integration Across Borders. EBRD Transition Report 2012. Retrieved from http://www.ebrd.com/downloads/research/transition/tr12.pdf

Fischer, S., Sahay R., \& Vegh C.A. (1998). From Transition to Market: Evidence and Growth Prospects. International Monetary Fund Working Paper 52. Retrieved from http://www.imf.org/external/pubs/ft/wp/wp9852.pdf

Eftimoski, D. (2006). Measuring quality of life in Macedonia - using human development indicators. The Proceedings of Rijeka Faculty of Economics - Journal of Economics and Business, 24(2), 257-272.

Havrylyshyn, O., Izvorski, I. \& van Rooden, R. (1998). Recovery and Growth in Transition Economies 1990-97: A Stylized Regression Analysis. IMF Working Paper, WP/98/141. Retrieved from http://www.imf.org/external/pubs/ft/wp/wp98141.pdf

Heritage Foundation. (2013). Index of Economic Freedom 2013. The Heritage Foundation in partnership with Wall street journal. Retrieved from www.heritage.org/index/ranking

Lovrinčević Ž., Mikulić D., \& Rajh E. (2008). Usporedba metodologija mjerenja konkurentnosti nacionalnog gospodarstva i položaj Hrvatske. Ekonomski Pregled, 59(11), 603-645.

Kendall, M.G. (1955). Rank Correlation Methods. New York: Hafner Publishing Co.

Kešeljević, A. (2007). Indexes of economic freedom - An outline and open issues. The Proceedings of Rijeka Faculty of Economics - Journal of Economics and Business, 25(2), 223-243.

Kose, A. M., \& Prasad, E. S. (2010). Resilience of Emerging Market Economies to Economic and Financial Development in Advanced Economies. Economic and Financial Affairs Economic Paper 411. Retrieved from http://ec.europa.eu/economy finance/publications/economic paper/2010/pdf/ec p411 en.pdf

Krstić, B., \& Stanišić, T. (2013). The Influence of Knowledge Economy Development on Competitiveness of Southeastern Europe Countries. Industrija, 41(2), 151167.

Minović J. (2011). Liquidity Measuring of Financial Market in Western Balkan Region: The Case of Serbia. Chapter 27 in Contemporary issues in the integration processes of Western Balkan countries in the European Union. Publisher: Ljubljana: International Centre for Promotion of Enterprises; Belgrade: Institute of Economic Sciences, pp. 443-459.

Minović, J. (2012). Liquidity of the Croatian Stock Market: An Empirical Analysis. Economic Research, 25(3), 776-802.

Quantitative Micro Software, LLC, EViews 7 User's Guide, www.eviews.com

Ranković, M., Vasković, V., \& Simović, V. (2012). Impact of inflation on the macroeconomic indicators in transition economies. Industrija, 40(2), 19-34.

Spearman, C. 1904. The proof and measurement of association between two things. American Journal of Psychology, 15, 72-101.

Stošić, I., Brnjas, Z. \& Dedeić, P. (2010). The impact of privatization on business performances and development of Serbian economy. Proceedings: The end of privatization, Edited by Drašković, B., Publisher: Institute of Economic Sciences, pp. 70-79.

Stošić, I., \& Erić, D. (2012). Challenges and perspectives of implementation structural changes in Serbian economy. In Managing structural changes: trends and re- 
Stošić I., Minović J.: Benchmarking Western Balkan Economies

quirements. Faculty of Economics of the University of Coimbra, Portugal, pp. 25-43.

Tošović Stevanović, A. (2011). Comparative analysis of indicators of international competitiveness. Megatrend revija, 8(2), 407-420.

World Bank/International Bank for Reconstruction and Development. (2013). Doing Business 2013, $10^{\text {th }}$ edition, Retrieved from http://www.doingbusiness.org/ /media/GIAWB/Doing\%20Business/Documents/ Annual-Reports/English/DB13-full-report.pdf and www.worldbank.org/

World Economic Forum. (2013). The Global Competitiveness Report 2012-2013. Retrieved from

http://www3.weforum.org/docs/WEF GlobalCompetitivenessReport 201213.pdf and www.weforum.org/ 